\title{
Care work - international perspectives and reflections
}

\author{
B. Aulenbacher $\cdot$ E. Gutiérrez Rodríguez $\cdot$ B. Liebig
}

(C) Springer Fachmedien Wiesbaden GmbH, ein Teil von Springer Nature 2018

Care is an issue with strong roots in Feminist and Gender Studies, and since the beginning of the $21^{\text {st }}$ century different strands of Sociology are 'discovering' it as one of the most pressing issues of our time. The meteoric rise of care and care work on the societal as well as sociological agenda is strongly related to the discussion of the crisis of social reproduction or the crisis of care. A closer look at this phenomenon and the care debate in general directs our attention at four aspects.

First, the discourse about the crisis of social reproduction and the crisis of care in Western Europe, initiated by debates headed by activists and scholars in Spain (Precarias a la Deriva 2004) and Italy (Sconvegno 2007) has highlighted the lack of care provision by the state and the increasing precariousness of care work as feminized and racialized labor (Gutiérrez Rodríguez 2014). After the global financial crisis in 2007/8, Western European governments have reacted to it by implementing austerity measures, causing in particular cuts in the areas of elderly, child and health care (Gavanas and Williams 2008). Subsequently, we are observing how austerity schemes lead to a return of precariousness and precarity and a decline of the welfare state, putting care provision at risk. In this context, research on the crisis of social reproduction and care engages with the analyses and critic of capitalism (Völker and Amacker 2015). Second, the contemporary capitalist organization of care provision

\footnotetext{
B. Aulenbacher $(\bowtie)$

Johannes Kepler University Linz, Altenberger Straße 69, 4040 Linz, Austria

E-Mail: brigitte.aulenbacher@jku.at

E. Gutiérrez Rodríguez

Justus-Liebig-University, Karl-Glöckner Straße 21E, 35390 Gießen, Germany

E-Mail: E.Gutierrez-Rodriguez@ sowi.uni-giessen.de

B. Liebig

University of Basel, Petersplatz 27, 4051 Basel, Switzerland

E-Mail: brigitte.liebig@fhnw.ch
} 
is mainly guided by marketization and privatization strategies, resulting in the forced commodification of care and care work. Within this context, care services become commodities and the persons needing care are treated as clients. New care markets in the field of child and elderly care are growing. More and more, to be able to be cared for has become an issue related to income and privilege. This is particular the case in societies in which the European welfare system has not shaped the state provision of care (Shire 2015). On this background, the analysis of care is central for the understanding of the political economy of contemporary societies and, in the Sociology of Care, questions of political economy have become more important than in the decades before (Aulenbacher et al. 2014; Fine 2007; Klenk and Pavolini 2015). Third, in the Global North we have been witnessing a far reaching change from the former Fordist male breadwinner to the adult worker model going along with new and more pluralistic modes of living and more egalitarian gender arrangements. On the one hand this involves a new division of labor between men and women as the discussion about fatherhood shows (Liebig and Oechsle 2017). On the other hand, increasingly paid care work is delivered by migrant women, working in some cases in "live-in" arrangements and employed as domestic workers. This is an internationally wide spread pattern defining the current reorganization of care and domestic work (Anderson and Shutes 2014; Brites and Gutiérrez Rodríguez 2014). Fourth, although some of the described constellations can be identified in the Global North and South and in Western and Eastern Europe, we are witnessing dramatic care gaps between these regions and between countries: The extent and quality of care provision differ between the established, the emerging, the declining and the rudimentary social states in the regions where welfare regimes have been established (Kofman and Raghuram 2015). In global care chains the care work delivered in the Global North is based on care arrangements and goes along with care gaps in the Global South and Eastern Europe (Apitzsch and Schmidbaur 2010; Anderson and Shutes 2014).

In July 2016, the University of Vienna hosted the $3^{\text {rd }}$ ISA Forum of Sociology, the interim congress of the International Sociological Association with more than 5000 participants from around the world. Herein the section 'Feminist Theory and Gender Studies' of the Austrian Sociological Association, the section 'Women's and Gender Studies' of the German Sociological Association and the committee 'Gender Studies' of the Swiss Sociological Association-represented by their speakers and the editors of this issue-successfully had applied to organize a common session. The idea behind has been to go global with the issue of care and care work and to analyze current trends in this field of debate and practice, which have to be seen strongly connected with the recent societal development. The articles published in this special issue are based on contributions made in this session.

These contributions touch on two levels that we, the editors, consider relevant for the publication of this special issue. First, they provide a critical and detailed theoretical understanding of care and care work. Second, the articles illustrate that international reach of the research on care and care work. This research is informed by empirical work based on case studies in Austria, Chile, Germany, India, Spain, the United States and the United Kingdom, and outline from a local perspective new tendencies and developments on a global scale. Therefore, the composition of the 
collection of articles includes a wide range of important issues of current research on care and care work as well as findings, insights and results concerning the current changes in the field.

In their article "Care economies-feminist contributions and debates in economic theory" the authors Sabrina Schmitt, Gerd Mutz and Birgit Erbe reflect on the debate on care in International Political Economy by focusing on the question: How is care provision organized in the different sectors-market, state, civil society, household-and how is this interrelated with social inequalities? How do feminist and other approaches explain these relations? Referring to core arguments of different theoretical strands they show how in the field of care questions of economy and social policy are discussed in an innovative way. Deepali Aparajita Dungdung's paper "Emergence of the care workforce in India: An interrogation of the contemporary labour market conditions" discusses the societal organization of care by focusing in particular on the role of the state as rudimentary care provider on the one hand, and the altered lifestyle driving new demands on the other hand. She reconstructs the rise of new care and labor markets in the last decade. Her article gives a profound overview on domestic care, nursing and some other fields of professional care. Care provision in India is interrelated with the availability of cheap labor and the author emphasizes that the state failed in case of the regulation and formalization of women's work. Rosario Fernandez discusses in her article "Commodification of domestic labor, the culture of servitude and the making of the Chilean state" current dynamics of the commodification of care and domestic work in Chile. Drawing on interviews with upper-class employers in Santiago and a review of the new domestic labor law and the state programme Chile Cuida (Chile Cares), she argues that the commodification of domestic labor is intensified in a neoliberal context, where colonial and modern modes of labor organisation and subjectivities co-exist. María Teresa Martín Palomo, Evangelina Olid González, Inmaculada Zambrano and Jose María Muñoz Terrón introduce in their article "Challenges in the professionalization of care in Andalusia" their research on Geographies of Care, and analyze the implications of the privatization of care work in the region of Andalusia in Spain. The paper analyzes how the implementation of the National Law for Personal Autonomy and Care for Dependent Persons, and the Royal Decree have shaped and regulated the employment relationships in private households. In this regard, it raises the question of the professionalization of care work in private households and discusses the challenges related to the implementation of these policies, and due to the effects of the financial crisis of 2007/08. The contribution of Ingrid Mayrhuber and Karin Sardadvar on "Employed family carers in Austria: The interplays of paid and unpaid work-beyond 'reconciliation'” critically reflects on concepts of reconciliation with respect to long-time care in Austria today. Based on policy analyses and qualitative empirical findings the authors show that a combination of paid work and informal long-time care is rarely possible. Up to date contradictory concepts of 'reconciliation policies' on state and 'work-life-balance' approaches on company level result in negative consequences for family carers with respect to financial issues and social security. Sylka Scholz' and Sophie Ruby's article titled "Care, care work and the struggle for a careful world from the perspective of the sociology of masculinities" starts from the observation, that-while in feminist research care and care work 
still remain associated with women - theories of masculinity barely integrate these issues. However, as the authors point out, men actually participate in several areas of care work, but their contribution is neither visible nor taken into consideration in contemporary debates about the transformation of gender relations. The concept of 'caring masculinities' still waits for a more detailed and empirically based sociological description and conceptualization. L. M. Anabel Stoeckles article titled "Outsourcing labor. Surrogacy as body care work" discusses surrogacy by referring to different dimensions of its negotiation in society. Starting with European policies in the field of surrogacy she explores ethical questions as well as the legislation. In both dimensions the status and acceptance of surrogacy are differing between countries. Furthermore it makes a difference if surrogacy is considered to be commercial or altruistic and paid or unpaid. Although such a framing is important to understand the perspectives on surrogacy it would not let us recognize its character situated between care and work. The author shows how care takes shape as a new unique form of "body care work".

We address our warm thanks to the Research Committee 32, Women in Society, in the International Sociological Association for hosting our common session in its stream on the $3^{\text {rd }}$ ISA Forum of Sociology Vienna 2016. Also we owe sincere thanks to the fourteen reviewers from around the world, who have been highly supportive with their country and care expertise, as well as to the Österreichische Zeitschrift für Soziologie, the journal of the Austrian Sociological Association, for their offer to publish this collection. On the $3^{\text {rd }}$ ISA Forum of Sociology the contributions drew a lot of attention and discussion. May the collection of the articles published here have the same effects.

\section{References}

Anderson, Bridget, and Isabel Shutes (eds.). 2014. Migration and care labour. Theory, policy and politics. Basingstoke: Palgrave Macmillan.

Apitzsch, Ursula, and Marianne Schmidbaur (eds.). 2010. Care und Migration. Die Ent-Sorgung menschlicher Reproduktionsarbeit entlang von Geschlechter- und Armutsgrenzen. Opladen, Farmington Hills: Barbara Budrich.

Aulenbacher, Brigitte, Birgit Riegraf, and Hildegard Theobald (eds.). 2014. Sorge: Arbeit, Verhältnisse, Regime_Care: Work, relations, regimes. Soziale Welt. Sonderband 20. Baden-Baden: Nomos.

Brites, Jurema, and Encarnación Gutiérrez Rodríguez (eds.). 2014. Domestic work between regulation and intimacy. Women's studies international forum, Vol. 46

Fine, Michael D. 2007. A caring society? Care and the human dilemmas in the 21 st century. Houndmills: Palgrave Macmillan.

Gavanas, Anna, and Fiona Williams. 2008. The intersection of child care regimes and migration regimes: a three-country study. In Migration and domestic work: a European perspective on a global theme, ed. H. Lutz, 13-28. London: Routledge.

Gutiérrez Rodríguez, Encarnación. 2014. The precarity of feminisation: on domestic work, heteronormativity and the coloniality of labour. International Journal of Politics, Culture, and Society 27(2):191-202.

Klenk, Tanja, and Emmanuele Pavolini (eds.). 2015. Restructuring welfare governance: marketisation, managerialism and welfare state professionalism. Aldershot: Edward Elgar.

Kofman, Eleonore, and Parvati Raghuram. 2015. Gendered migrations and global social reproduction. Basingstoke: Palgrave Macmillan.

Liebig, Brigitte, and Mechthild Oechsle (eds.). 2017. Fathers in work organizations: inequalities and capabilities, rationalities and politics. Opladen: Barbara Budrich. 
Precarias a la Deriva. 2004. A la deriva por los circuitos de la precariedad feminina. Madrid: Traficantes de Sueños.

Sconvegno (Manuela Galetto, Chiara Lasala, Sveva Magaraggia, Chiara Martucci, Elisabetta Onari, Francesca Pozi). 2007. A snapshot of precariousness: Voices, perspectives, dialogues. Feminist Review 87:104-112.

Shire, Karen. 2015. Family supports and insecure work: the politics of household service employment in conservative welfare regimes. Social Politics: International Studies in Gender, State \& Society 2:193-219.

Völker, Susanne, and Michèle Amacker (eds.). 2015. Prekarisierungen. Arbeit, Sorge, Politik. Weinheim, Basel: Beltz Juventa.

B. Aulenbacher Dr. rer. soc., hab. soc., professor for sociological theory and social analysis, head of the Department for the Theory of Society and Social Analyses at the Institute of Sociology, Johannes Kepler University Linz. She has been the speaker of the Section Feminist Theory and Gender Studies of the Austrian Sociological Association (2013-2017). Her research focuses on the theory of society, sociology of work and of care, gender and organization studies.

E. Gutiérrez Rodríguez professor in general sociology and head of the Institute of Sociology at the Justus-Liebig-University Giessen. She is first speaker of the board of the Women and Gender Studies Section in the German Sociology Association. Her main research is on affective labor, de/coloniality, European asylum-migration regimes.

B. Liebig Dr. phil., hab.soc., is professor for organizational science, University of Applied Science Northwestern Switzerland, and private lecturer at the Department of Sociology, University of Basel. She is speaker of the gender studies committee of the Swiss Sociology Association. Her research focuses on gender, work, entrepreneurship and organization, and provision of care at the end of life. 